\title{
From Sea to Shining Sea: How and Why Class Actions Are Spreading Globally
}

\author{
Deborah R. Hensler ${ }^{1}$
}

\section{INTRODUCTION}

In recent years, as the U.S. Supreme Court has steadily closed the courthouse doors to class actions in the United States, ${ }^{2}$ an increasing number of foreign jurisdictions have adopted some form of representative group proceeding along the lines of a modern class action. Perhaps not surprisingly given the roots of the American class action in England's medieval group litigation, ${ }^{3}$ outside the United States, class action procedures were adopted in the common-law jurisdictions of Australia and Canada before most civil law jurisdictions followed suit (Quebec, the Francophone Canadian province that is governed by civil law, is the exception to this generalization: it adopted a class action

\footnotetext{
1. Judge John W. Ford Professor of Dispute Resolution, Stanford Law School. This essay draws on my

contributions to the co-edited book, CLASS ACTIONS IN CONTEXT: HOW CULTURE, ECONOMICS AND Politics Shape Collective Litigation (Deborah Hensler, Christopher Hodges \& Ianika Tzankova eds., 2016) [hereinafter ClASS ACTIONS IN CONTEXT].

2. See generally Robert H. Klonoff, The Decline of Class Actions, 90 WASH. U. L. REV. 729 (2013); Robert G. Bone, Walking the Class Action Maze: Toward a More Functional Rule 23, 46 U. MiCH. J.L. REFORM 1097 (2013). Cases interpreting FED. R. CIV. P. 23 certification requirements in a more restrictive fashion than previous holdings or otherwise restricting plaintiffs' ability to proceed in a class form include Wal-Mart Stores, Inc. v. Dukes, 131 S. Ct. 2541 (2011) (vacating certification of a class of female employees, applying a heightened commonality standard); Comcast Corp. v. Behrend, 133 S. Ct. 1426 (2013) (vacating certification of an anti-trust class, on the grounds that the damage model did not fit the class definition); AT\&T Mobility LLC v. Concepcion, $131 \mathrm{~S}$. Ct. 1740 (2011) (upholding the validity of an arbitration clause denying consumers' right to proceed in class form); and Am. Express Co. v. Italian Colors Rest., 133 S. Ct. 2304 (2013) (holding that prohibiting class members from proceeding in a collective arbitration procedure when such a prohibition effectively denies plaintiffs the ability to vindicate their rights is not sufficient to void the arbitration provision). Arguably, in more recent cases, a majority of Supreme Court justices have rejected efforts to further restrict rights of plaintiffs to proceed in class form. E.g., Halliburton Co. v. Erica P. John Fund, Inc., 134 S. Ct. 2398 (2014) (maintaining "fraud on the market" as a substitution for individual reliance in securities litigation, thereby allowing plaintiffs to offer proof of commonality); Campbell-Ewald Co. v. Gomez, 136 S. Ct. 663 (2016) (holding that representative plaintiff's rejection of an offer of settlement does not automatically moot the litigation).

3. See generally Stephen C. Yeazell, From Medieval Group Litigation to the MODERN CLASS ACTION (1987) (describing the modern class action's relationship with medieval group litigation).
} 
procedure in 1978). ${ }^{4}$ Australia and Canada will both celebrate the twenty-fifth anniversary of their class action procedures in 2017, twentyfive years after the 1966 birth of the modern U.S. class action. However, the spread of class action procedures globally began in earnest in the 2000s. Today, at least thirty-five jurisdictions in addition to Australia, Canada, and the United States, including twenty-one of the twenty-five largest economies in the world, permit class actions for some or all legal claims (See Table 1). ${ }^{5}$ These procedures are authorized by statute, rule, or, in some instances, by constitutions or judicial decisions. The procedures differ in many respects; their common feature is that they allow one or a few persons or entities to represent a large number of similarly situated claimants in a legal action seeking a substantive remedy. This procedural form differs sharply from traditional courtbased dispute resolution, involving one or a few claimants suing one or a few defendants for relief. It also differs from traditional joinder, in which multiple parties are before the court. Typically, in a representative class action, save for the class representative, the class members are "absent parties."

In this essay, I discuss the possible reasons for this remarkable diffusion of a "legal transplant," identify the key features of the procedures that influence the extent and nature of their application, discuss alternatives to class actions such as aggregated group proceedings and administrative compensation schemes, and consider the implications for the future of the global expansion of collective litigation.

4. W.A. Bogart, Questioning Litigation's Role - Courts and Class Actions in Canada, 62 Ind. L.J. 665, 685-89 (1987).

5. See generally ClASS ACTIONS IN CONTEXT, supra note 1. There is no official compendium of jurisdictions with class actions. With colleagues in Europe, I have been monitoring the spread of class actions over the last decade. 
Table 1

COUNTRIES THAT HAVE ADOPTED A CLASS ACTION

FOR ONE OR MORE TYPES OF LEGAL CLAIMS

\begin{tabular}{|c|c|c|c|c|}
\hline $\begin{array}{c}\text { NORTH } \\
\text { AMERICA }\end{array}$ & $\begin{array}{l}\text { CENTRAL } \\
\& \text { SOUTH } \\
\text { AMERICA }\end{array}$ & $\begin{array}{c}\text { EUROPE }^{6} \\
\& \text { THE } \\
\text { MIDDLE } \\
\text { EAST }\end{array}$ & AFRICA & $\begin{array}{c}\text { ASIA \& } \\
\text { AUSTRALASIA }\end{array}$ \\
\hline Canada & Argentina & Belgium & $\begin{array}{l}\text { South } \\
\text { Africa }\end{array}$ & Australia \\
\hline Mexico & Bolivia & Bulgaria & & China \\
\hline \multirow[t]{14}{*}{$\begin{array}{l}\text { United } \\
\text { States } \\
\end{array}$} & Brazil & Denmark & & Indonesia \\
\hline & Chile & $\begin{array}{l}\text { England \& } \\
\text { Wales }\end{array}$ & & Japan \\
\hline & Costa Rica & Finland & & South Korea \\
\hline & Colombia & France & & Taiwan \\
\hline & Ecuador & Israel & & Thailand \\
\hline & Panama & Italy & & \\
\hline & Peru & Lithuania & & \\
\hline & Uruguay & Netherlands & & \\
\hline & Venezuela & Norway & & \\
\hline & & Poland & & \\
\hline & & Portugal & & \\
\hline & & Spain & & \\
\hline & & Sweden & & \\
\hline & & Ukraine & & \\
\hline
\end{tabular}

6. The European Commission has adopted non-binding "Principles on Collective Redress," the term adopted in Europe to distinguish their approach to collective litigation from the American class action. See Commission Recommendation of 11 June 2013 on common principles for injunctive and compensatory collective redress mechanisms in the Member States concerning violations of rights granted under Union Law (2013/396/EU), OFFICIAL JOURNAL OF THE EUROPEAN UnION (July 26, 2013) [hereinafter European Commissions Principles on Collective Redress], http://eur-lex.europa.eu/legal-content/EN/TXT/PDF/?uri=CELEX:32013H0396\&from=EN. 


\section{WHAT EXPLAINS THE SPREAD OF ClASS ACTIONS?}

Because the modern class action was first adopted in the United States and because most jurisdictions that have adopted the class action in the last decade refer to the "American class action" as a model, if not to emulate then to avoid, it is reasonable to view class actions outside the United States as "legal transplants." There is rich literature on the global diffusion of ideas and practices generally, and the diffusion of legal policies and practices in particular. ${ }^{7}$ Scholars have proposed a variety of explanations for such diffusion, including coercion by external forces, simple emulation, rational policy making, and competition. No one has yet undertaken a systematic analysis of the causes for the spread of class actions, but it appears to be the result of a mix of factors including some but not all of the above.

Imperialists took their legal norms and practices to the nations they conquered, often adapting them so as to serve their own interests. There is no example, however, of a country that has adopted a class action procedure as a result of coercion by external forces; to the extent that external forces have been at work, it has been to oppose the adoption of a class action in a new jurisdiction. ${ }^{8}$ There is some evidence of simple emulation in the timing of class action adoption: once one country in a region has adopted a class action, it appears to be more likely that others will follow. For example, an early wave of adoption of class actions in Northern Europe was only recently followed by a similar wave in Western Europe, and the pattern is now extending itself in Central and Eastern Europe and in Asia. It is not clear that all these waves of adoption were responsive to particular policy challenges. However, these patterns might be explained by rational decision-making in which a country facing a problem for which a class action might offer a solution

7. See generally Alan Watson, Legal Transplants: An Approach to Comparative LAW (1974); MiChELE GRAZIADEI, Comparative Law as the Study of Transplants and Receptions, in THE OXFORD HANDBOOK OF COMPARATIVE LAW (Mathias Reimann \& Reinhard Zimmermann eds., 2006); Frank Dobbin, Beth Simmons \& Geoffrey Garrett, The Global Diffusion of Public Policies: Social Construction, Coercion, Competition, or Learning?, 33 ANN. REv. OF Soc. 449 (2007). Although Watson is often cited as the first to propose the term "legal transplant," he objected to its use to describe the spread of legal concepts that spread gradually, rather than as a result of an abrupt decision.

8. Deborah Hensler, Can Private Class Actions Enforce Marketplace Regulations? Do They? Should They?, in COMPARATIVE LAW AND RegUlATION: NATIONAL, INTERNATIONAL AND Transnational Perspectives (Francesca Bignami \& David Waring eds., 2016) [hereinafter Hensler, Enforce Marketplace Regulations]. On the campaign by the U.S. Chamber of Commerce to forestall adoption of class actions outside the United States, see Deborah R. Hensler, Third-Party Financing of Class Action Litigation in the United States: Will the Sky Fall?, 63 DEPAUL L. ReV. 499 (2014) [hereinafter Hensler Third-Party Financing]. 
looks to its neighbors for an example of successful policy adoption and implementation. The rise of mass claims, which by their nature require a collective approach to resolution, is likely an example of the sort of challenge that inspires problem-solving efforts. ${ }^{9}$ The regional spread of class actions might also be explained by competition, however; when the Netherlands adopted a creative approach to settling mass claims collectively and advertised itself as the preferred forum for such settlements, it led to discussions in the United Kingdom about assuring that its courts did not lose "business" to the Dutch. ${ }^{10}$ Not as frequently discussed in the legal transplant literature is the role of legal education. The rise of LLM programs in American law schools targeting international students has inadvertently provided the opportunity for thousands of foreign legal practitioners to learn about the U.S. class action. ${ }^{11}$ Promoting the adoption of a new high-profile procedure upon their return to their home jurisdictions may convey special status and lead to new professional opportunities for these (mostly young) practitioners. $^{12}$

The role of mass claims in propelling the adoption of class actions should not be underestimated. In the United States, courts frequently manage mass claims by informal and formal aggregation (e.g. the federal multi-district litigation procedure authorized by 28 U.S.C. $\S 1407$ and its state look-alikes) $)^{13}$ rather than class actions, particularly in personal injury and property damage litigation that cannot meet the predominance requirement for certification of damage class actions under FED. R. CIV. P. 23(b)(3). Most other jurisdictions do not have formal procedures for aggregating individual claims (other than the class action), and the case management demands of both informal and formal claim aggregation are discomforting to judges. ${ }^{14}$

9. On the rise of mass claims, see Deborah Hensler, Justice for the Masses? Aggregate Litigation \& its Alternatives, 143 DAEDULus 73, 73-82 (2014) [hereinafter Hensler, Justice for the Masses], see also Deborah Hensler, How Economic Globalisation is Helping to Construct a Private Transnational Legal Order, in THE LAW OF THE FutURE AND THE FUTURE OF THE LAW (Sam Muller et al. eds., 2011).

10. Hensler, Enforce Marketplace Regulations, supra note 8, at 241.

11. Id. at 242 .

12. For discussion of how diffusion of legal practices internationally may convey power and social status to practitioners, see Yves Dezalay \& Bryant G. Garth, DEALING IN ViRTUE: INTERNATIONAL COMMERCIAL ARBITRATION AND THE CONSTRUCTION OF A TRANSNATIONAL LEGAL ORDER (1st ed. 1996).

13. Hensler, Justice for the Masses, supra note 9, at 73-82.

14. See generally Ianika N. Tzankova, Case Management: The Stepchild of Mass Claim Dispute Resolution, 19 UNIF. L. REV. 329 (2014). For a discussion of case management in U.S. courts, see Steven S. Gensler, Judicial Case Management: Caught in the Crossfire, 60 DuKE L.J. 669 (2010). 
Today, in most democratic industrialized countries when serious injuries or substantial financial losses give rise to mass claims, litigation ensues. $^{15}$ In most jurisdictions, class actions were adopted chiefly to facilitate resolving such claims. ${ }^{16}$ However, facilitating meritorious claims that would not otherwise be litigated because the amounts at issue are too small has contributed to the adoption of class actions in some jurisdictions. Canada and Australia are two jurisdictions whose class action jurisprudence highlights access to justice concerns; ${ }^{17}$ access to justice for small value consumer claims also helped propel the adoption of the European Principles on Collective Redress. ${ }^{18}$ In contrast, opposition to the adoption of class action procedures in many jurisdictions is grounded on beliefs that providing such a procedure will encourage a "flood of frivolous litigation," 19 often perceived as comprising small value claims.

Another possible objective of class actions, private enforcement of public regulations (the so-called "private attorney general" theory) is more contentious. The notion of using private litigation to supplement legal enforcement by government agencies is familiar to common law jurists and legal practitioners and to scholars trained in the economic analysis of law, which highlights the deterrence function of civil litigation. $^{20}$ But it is anathema to many in civil law jurisdictions that have a long tradition of reliance on public institutions to ensure legal compliance. In recognition of this, during years of European Union controversy over the adoption of class actions, representative collective procedures were christened "collective redress" mechanisms, and the

15. For a discussion of the cultural phenomena of mass claiming, see Byron Stier \& Ianika Tzankova, The Culture of Collective Litigation: A Comparative Analysis, in CLASS ACTIONS IN CONTEXT, supra note 1.

16. See e.g., Ianika Tzankova \& Daan Lunsingh Scheurleer, The Netherlands, in THE Globalization of Class Actions (Deborah R. Hensler, Christopher Hodges, \& Magdalena Tulibacka eds., 2009); see also CLASS ACTIONS IN CONTEXT, supra note 1, at 391-93.

17. P. Dawson Nominees Pty. Ltd. v. Multiplex Ltd. [2007] 242 ALR 111 (Federal Court of Australia) (Austl.); Western Canadian Shopping Centres Inc. v. Dutton, [2001] 2 S.C.R. 534 (Can.).

18. European Commissions Principles on Collective Redress, supra note 6.

19. John Beisner, Jessica Miller, \& Gary Rubin, Selling Lawsuits, Buying Trouble: ThirdParty Litigation Funding in the United States, U.S. CHAMBER OF COMMERCE INSTITUTE FOR LEGAL REFORM

(2009),

http:/www.instituteforlegalreform.com/uploads/sites/1/thirdpartylitigationfinancing.pdf.

20. See ClASS ACTIONS IN CONTEXT, supra note 1, at 271-72 (briefly discussing deterrence theory as it applies to the private enforcement objective of class actions, including citations to key literature and court decisions). Although scholars and lobbyists argue over the appropriate boundary to set between public and private enforcement, qualitative case studies of litigation arising after mass injuries or losses occur indicate that responses are almost always a mix of public and private action. Id. at 259-78 (highlighting the interaction of public and private enforcement observed in qualitative case studies of litigation in multiple jurisdictions). 
European Commission's Principles on Collective Redress caution against (but do not entirely prohibit) using private class actions for regulatory enforcement. $^{21}$

\section{VARIATIONS IN CLASS ACTION DESIGN}

Not all class actions are created equal. The key features of class action design differ significantly, reflecting both the differences in policy objectives discussed above and differences in jurisdictions' legal history and culture. Moreover, the legal regimes in which class actions operate also differ in important respects. Together these differences in procedural features and legal regimes shape the implementation of class actions and their outcomes.

Four differentiating features of class actions have proved most important: substantive scope, rules on standing of class representatives, whether class members need to proactively join or proactively exclude themselves from the collective litigation ("opt-in" versus "opt-out") and availability of monetary remedies.

Logically, when authority to proceed in class form is transsubstantive or authorized for many different types of legal claims it is more likely that class actions will be filed in court. Alternatively, when the use of class actions is limited to a single area of law, the procedure will only be used for claims grounded on that law. Australia, Canada, and the United States are examples of jurisdictions with trans-substantive class action procedural rules; Israel's procedure is not formally transsubstantive but its use is authorized for a wide range of case types. Belgium, Chile, France, and Japan are examples of jurisdictions that have adopted class actions for consumer claims. England recently adopted a class action procedure for anti-competition (antitrust) claims. Taiwan authorizes class actions for shareholder claims. ${ }^{22}$ There is some evidence that once a legislature (or the judiciary) authorizes a class action for one type of claim, the procedure may later be used for other types of claims. Israel's and France's current class action regimes reflect

21. European Commissions Principles on Collective Redress, supra note 6. The European Commission engaged in long years of controversy over the question of whether to adopt a directive mandating the adoption of a class action procedure by member states, during which the Commission (and lobbyists) produced multiple reports and tentative recommendations. Unable to reach consensus, in June 2013 the Commission issued a set of recommended principles for designing collective litigation mechanisms throughout the EU. See id.

22. Germany's group litigation procedure (the KapMuG), which is not a class action, is authorized for shareholder claims. 
this sort of historical expansion. ${ }^{23}$ The Netherlands' unique collective settlement procedure (the WCAM) was adopted to provide a mechanism for resolving product liability claims arising out of health injuries associated with the DES drug but was rapidly adopted for use in

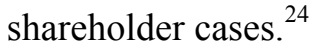

Table 2

Key Design Features of Class Actions

\begin{tabular}{|l|c|c|}
\hline Scope & $\begin{array}{c}\text { Facilitate Class } \\
\text { Actions }\end{array}$ & $\begin{array}{c}\text { Restrict Class } \\
\text { Actions }\end{array}$ \\
\hline Standing & Trans-substantive & $\begin{array}{c}\text { One or a few areas of } \\
\text { law }\end{array}$ \\
\hline $\begin{array}{l}\text { Becoming a Class } \\
\text { Member }\end{array}$ & $\begin{array}{c}\text { Representative Class } \\
\text { Member }\end{array}$ & $\begin{array}{c}\text { Authorized } \\
\text { organizations or public } \\
\text { officials }\end{array}$ \\
\hline Remedies & $\begin{array}{c}\text { Opt-out } \\
\text { well as injunctive or } \\
\text { declaratory relief }\end{array}$ & Opt-in \\
\hline
\end{tabular}

Procedures for determining whether it is appropriate for a substantively eligible complaint to proceed in class form differ among jurisdictions. Canada and the United States have formal certification procedures $^{25}$, which in the United States have become so strict in recent years that the certification process may turn into a mini-trial of the merits. Australia does not require that a judge certify a complaint before it can proceed in class form, but if a defendant challenges class treatment it will set off a judicial inquiry into whether the characteristics of the case - numerous plaintiffs, common issues, etc.- are such that class treatment is appropriate. ${ }^{26}$ In civil law jurisdictions, perhaps because of

23. Deborah Hensler, The Globalization of Class Actions: An Overview, in THE GLOBALIZATION OF Class ACTIONS, supra note 16 (reporting features of different countries' classaction regimes) [hereinafter Hensler, Overview].

24. Deborah Hensler, The Future of Mass Litigation: Global Class Actions and Third-Party Litigation Funding, 79 GEO. WASH. L. REV. 306, 311-13 (2011).

25. Jasminka Kalajdzic, W. A. Bogart \& Ian Mathews, Canada, in ThE Globalization of Class ACtions, supra note 16. In the United States, FED. R. CiV. P. 23 specifies the requirements for certifying federal class actions.

26. Vince Morabito, Australia, in The Globalization of Class ACtions, supra note 16. 
the recency of adoption of class action procedures, the rules for determining whether a case should proceed in class form seem sketchier.

All of the common-law jurisdictions that have adopted class actions to date permit class members (individuals or entities such as businesses) to offer themselves as representatives of the class, subject to a judge's determination that the representative's claims are typical of other class members and that they can adequately represent the class members' interests. In jurisdictions that require certification, adequacy of representation is frequently interpreted as referring to the availability of financial resources to prosecute the claim - a substantial issue when the class is suing a well-resourced domestic or multinational corporationand the engagement of legal counsel with expertise in class litigation. However, a court's inquiry into adequacy may also raise the question of whether the class members' interests are sufficiently homogeneous that the proposed class representative can represent them without a conflict. In Amchem Products Inc. v. Windsor the U.S. Supreme Court ruled that a class of asbestos exposed victims were situated so differently that they could not be adequately represented by the proposed representative. ${ }^{27}$ The holding seemed to sound the death knell for all personal injury class actions going forward, but by suggesting that creating separately represented "sub-classes" might solve the problem of adverse interests within a class, the court left a door open that some class actions have been able to march through. ${ }^{28}$

Civil law jurisdictions that have adopted class action procedures have generally limited standing to represent the class either to public officials or quasi-public agencies (the approach of Brazil, Denmark, and Taiwan) or to pre-existing associations or special purpose foundations (the approach of Belgium, France, the Netherlands, and Japan). ${ }^{29}$ The theory behind these choices seems to be that class members represented by private lawyers are more likely to be susceptible to principal-agent conflicts, leading to settlements of claims that will advantage the representative plaintiff over the class or the class counsel over class members (or both). However, experience shows that public officials are susceptible to political pressures to bring or reject bringing class

27. Amchem Products Inc. v. Windsor, 521 U.S. 591, 625-28 (1997).

28. See In re NFL Players Concussion Injury Litig., 821 F.3d 410, 421 (2016) (upholding class certification and approval of a settlement of NFL Players' personal injury litigation).

29. See generally, Hensler, Overview, supra note 23 (reporting features of different countries' class-action regimes). Chile is an example of a jurisdiction that confers standing on both a public agency and individual class members. 
actions, ${ }^{30}$ and that non-profit associations and special purpose foundations are subject to conflicts of interest as well. ${ }^{31}$ In brief, agency problems are inherent in all forms of collective litigation. ${ }^{32}$

Common law and civil law jurisdictions also differ with regard to preference for "opt-out" versus "opt-in" class action procedures. Australia, Canada, Israel, and the United States all have opt-out procedures for civil damages class actions, while most of western and northern European jurisdictions have adopted opt-in procedures, and the European Commission's recommended principles for so-called collective redress mechanisms sternly admonish member states to eschew opt-out procedures. $^{33}$ Notwithstanding this advice, some civil law jurisdictions such as Spain - a relatively early adopter - and Lithuania and Polandmore recent adopters - have chosen the opt-out approach. The Netherlands' unique collective settlement mechanism (WCAM) - which is available only to claimants and defendants who have agreed to settle before approaching the court-is also an opt-out mechanism. The principled argument against opt-out class actions is that claimants run the risk of losing their right to bring a claim if they are unaware that they have been included in a certified class that has disposed of all class members' claims. Requirements to provide extensive notice, both on an individual and mass basis, are intended to mitigate this problem, ${ }^{34}$ but as a practical matter there will always be a possibility that some class members are swept into an opt-out class action without realizing that this has occurred. Notwithstanding the importance of these normative and practical concerns, in reality opposition to opt-out class actions is driven

30. See Agustin Barroilhet, Self-Interested Gatekeeping? Clashes Between Public and Private Enforcers in two Chilean Class Actions, in CLASS ACTIONS IN CONTEXT, supra note 1; see also Kuo-Chang Huang,

Using Associations as a Vehicle for Class Action: The Case of Taiwan, in Class ACTIONS IN CONTEXT, supra note 1 .

31. Ianika Tzankova, Everything You Wanted to Know about Dutch Foundations but Never Dared to Ask: A Checklist for Investors, TILBURG LAW SCHOOl Legal StUdies RESEARCH PAPER SERIES (Feb. 10, 2016), http://papers.ssrn.com/sol3/papers.cfm?abstract_id=2730618. For examples of recent Dutch Foundations established to seek damages on behalf of investors, see BP INVESTOR Claims FOUNDATION, https://bpinvestorfoundation.com/, and THE VOLKSWAGEN INVESTOR SETTLEMENT FOUNDATION, http://volkswageninvestorsettlement.com/governance/.

See also Ianika Tzankova, Collective Redress in Vie d'Or: A Reflection on a European Cultural Phenomenon, in CLASS ACTIONS IN CONTEXT, supra note 1, at 117-36

32. While agency issues may also arise in litigation between single represented parties, there is good reason to believe that the potential for conflict between class counsel and the class they represent is greater, because of the difficulty absent parties face in monitoring their representatives.

33. See European Commissions Principles on Collective Redress, supra note 6.

34. On the relationship of due process to notice in class actions in U.S. law, see Phillips Petroleum Co. v. Shutts, 472 U.S. 797 (1985). 
largely by interest group politics: sophisticated parties understand that opt-out classes are likely to be larger than opt-in classes because (as demonstrated by empirical studies ${ }^{35}$ ) individuals are less likely to proactively take steps to join an activity than to passively allow themselves to be included in the activity. As a result, opt-out class actions give the class (and class counsel) more leverage against defendants.

Finally, all jurisdictions that provide for collective litigation offer injunctive or declaratory relief as a remedy, but many restrict class members' ability to collect money damages. ${ }^{36}$ The rationale for the restriction on money damages relates to the rationale for opt-in provisions: if money is at stake, class members arguably have a greater stake in pursuing an individual claim. The politics of the debate over remedies also matches the politics of the debate over opt-out versus optin: if those who have suffered a loss as a result of a defendant's legal violation can band together to pursue a remedy, they are more likely to be successful; hence, permission to proceed collectively increases the likelihood that defendants will be called to account for bad behavior. ${ }^{37}$ Moreover, when there is an expectation of money damages, entrepreneurial lawyers, membership organizations, and special purpose foundations are all more likely to believe it is worthwhile to invest resources in pursuing legal claims.

Allowing money damages in class actions creates challenges when the class is large and when losses vary among class members. Even when common issues of law and fact justify collective treatment, allocating damages obtained at trial or in settlement to individual class

35. Health and education policy researchers have conducted systematic research on differences in participation rates using active (i.e. opt-in) versus passive (i.e. opt-out) consent. Generally, researchers find higher participation rates under passive consent conditions albeit little differences in the characteristics of the participant groups. See, e.g. Suzanne Spence et al. Does the use of passive or active consent affect consent or completion rates, or dietary data quality? Repeat cross-sectional survey among school children aged 11-12 years, 2015 BMJ OPEN (Jan. 13, 2015), http://bmjopen.bmj.com/content/5/1/e006457.info.

36. See generally Hensler, Overview, supra note 23.

37. This understanding produced the drive in the United States to include arbitration provisions prohibiting any form of collective proceeding in a wide range of consumer, employment, and other business contracts. In the past decade, the U.S. Supreme Court has upheld such contractual provisions. See AT\&T Mobility LLC v. Concepcion, 131 S. Ct. 1740 (2011) (upholding the validity of an arbitration clause denying consumers' right to proceed in class form); see also Am. Express Co. v. Italian Colors Rest., 133 S. Ct. 2304 (2013) (holding that prohibiting class members from proceeding in a collective arbitration procedure when such a prohibition effectively denies plaintiffs the ability to vindicate their rights is not sufficient to void the arbitration provision). In Europe, including mandatory arbitration clauses in form contracts is considered a violation of the European Convention on Human Rights. 
members may impose logistical challenges. Precise eligibility and loss determination rules must be designed and communicated to class members and systems devised for delivering payments. In some circumstances in the United States, plaintiff and defense counsel have collaborated on designing special purpose facilities for delivering compensation to mass tort claimants. ${ }^{38}$

However, in consumer class actions and other financial damage class actions, it appears more common for the parties or lawyers to contract with for-profit claims administration companies to administer class settlements. Civil law judges have little experience addressing the distribution of monetary compensation, which may contribute to wariness in civil law jurisdictions about permitting class actions for money damages. Ironically, the politics in Europe that have promoted the use of class actions for "collective redress" rather than regulatory enforcement may promote the development of effective approaches to delivering compensation to claimants in mass litigation, which might in turn encourage more jurisdictions to expand class action remedies to include money damages.

Taken together, broad authorization for class actions, rules granting standing to class members, opt-out provisions, and availability of money damages all make it more likely that class action procedures will actually be used in the jurisdictions that have adopted them, rather than remain simply "law on the books." At least as important as each of these features, however, is the legal financing regime within which the class action procedure must operate. ${ }^{39}$ Class actions, like all complex lawsuits, are expensive. Without adequate resources, class representatives, whether individuals or associations (and even whether private or public), cannot effectively prosecute class actions and are therefore unlikely to even attempt to use the procedure.

United States legal financing rules are the most favorable to class litigation: lawyers are permitted to bring class actions on a speculative basis, meaning that they can invest their own resources and if successful

38. See generally Mark A. Peterson, Giving Away Money: Comparative Comments on Claims Resolution Facilities, 53 LAW \& CONTEMP. PROB. 113, (1990) (describing these special purpose facilities); Deborah Hensler, Assessing Claims Resolution Facilities: What We Need to Know, 54 LAW \& CONTEMP. PROB. 175_(1991); Deborah Hensler, Alternative Courts? Litigation-Induced Claims Resolution Facilities, 57 STAN. L. REV. 1429 (2005); Francis McGovern, The What and Why of Claims Resolution Facilities, 57 STAN. L. REV. 1361 (2005).

39. For comparative information on fee regimes, see NEW TRENDS IN FINANCING CIVIL LiTigATION IN EUROPE (Mark Tuil \& Louis Visscher eds., 2010) and THE COSTS AND Funding OF Civil Litigation: A Comparative Perspective (Christopher Hodges, Stefan Vogenauer \& Magdalena Tulibacka eds., 2010). 
earn a premium on their investment. ${ }^{40}$ Moreover, under the "American fee rule" that specifies that each side will bear its own litigation costs, neither the class nor class counsel faces the threat of adverse costs. Under equitable fee doctrine, if the class prevails all of the class members will pay a share of attorney fees and expenses proportionate to the damages they obtain, eliminating the potential for free-riding. Bringing a class action is still a high-stakes investment for lawyers, since if defendants prevail the class counsel will receive nothing to cover his or her time or expenses. Furthermore, the class counsel is not permitted to set his or her own fee, because in class actions, unlike ordinary civil litigation, the judge decides what the prevailing class counsel will receive. ${ }^{41}$ Nonetheless, an experienced class action litigator can expect to achieve financial success by carefully selecting and prosecuting class actions. ${ }^{42}$

This is less true in other jurisdictions. In most Canadian provinces, class counsel may charge contingent fees (although judges provide some oversight of fee arrangements), but class members do face adverse costs. In a few Canadian provinces, including Ontario and Quebec, public funds have been established to take on the risk of adverse costs. The funds are replenished by charging successful class members a small fraction of the total award or settlement for the class. ${ }^{43}$

In Australia, lawyers are allowed to represent a class representative on a "no win, no pay" basis but are barred from charging fees based on the amount obtained for the class and the class representative faces adverse costs if the defendant prevails. Successful class counsel may receive an "upcharge" on their hourly fees but that is limited to twentyfive percent. The class representative is legally responsible for the full adverse costs if defendants prevail and class members other than the representative have no obligation to contribute to paying class counsel if the class prevails, creating an obvious "free-rider" problem. ${ }^{44}$ In most

40. On funding of U.S. class actions generally, see THE GLOBALIZATION OF Class ACtions, supra note 16 , at $22-23$.

41. FED. R. CIV. P. 23(h). Depending on fee doctrine within the federal circuit, in federal courts class counsel fees will either be awarded on a percentage-of-fund basis or on a "lodestar" basis (hours $\mathrm{x}$ hourly rate $\mathrm{x}$ multiplier). Across all federal class action settlements in recent years, class counsel fees averaged about twenty-two percent of negotiated settlement funds, with the percent declining as the size of the fund increased. See Theodore Eisenberg \& Geoffrey P. Miller, Attorneys' Fees and Expenses in Class Action Settlements: 1993-2008, 7 J. OF EMPIRICAL LeGAL StUD. 248 (2010) and Brian Fitzpatrick, An Empirical Study of Class Action Settlements and their Fee Awards, 7 J. OF EMPIRICAL LEgAL STUD. 811 (2010).

42. Hensler, Overview, supra note 23, at 23-24.

43. Id. at 24 .

44. Id. 
civil law jurisdictions, there is no provision for "no win, no pay" legal representation of the class; class counsel must charge on an hourly basis (although in some jurisdictions "success fees" are permitted on top of hourly charges), the class representative faces adverse costs and there is no scheme for avoiding free-rider problems. ${ }^{45}$

As a result of legal financing regimes, the prospects for class actions in many jurisdictions seem grim, however friendly to claimants the class action procedures themselves may appear. The reality, however, is considerably more propitious: in response to restrictions on fees and to adverse cost rules, third-party funders have appeared, first in Australia and now in Europe, Canada, and even the United States (where such financing seems least necessary). These third-party funders take different forms and apply different protocols, but in class actions the general approach is for third-parties to contract with individual class members to pay lawyer fees (while the litigation is ongoing) and take on the risk of adverse costs. ${ }^{46}$ In return, the class members agree to pay the funders a hefty share of any damages they obtain; as the funders are not themselves lawyers, they are not barred from charging such contingent fees and in most jurisdictions to date their charges have not been regulated. Third-party financers are themselves funded by hedge funds, high-value individuals, and others looking for attractive investment opportunities that are not correlated with trends in the capital markets. Third-party funding works well in opt-in class action regimes where class members must identify themselves in order to join the litigation and in regimes where standing is limited to pre-existing associations (for which third-party funding may operate like a line of credit) and special purpose foundations that are legally authorized to enter into such financing agreements. In formally opt-out regimes where class members have standing to represent the class, the practical effect of third-party funding is to convert the class action to an opt-in procedure. ${ }^{47}$

Another "work-around" that has emerged in jurisdictions with

45. Id. at $22-23$.

46. In the United States, third-party funders have generally asserted they will not fund class actions, perhaps in an effort to insure their preferred commercial corporate clients that the funders are not a threat. See Hensler, Third-Party Financing, supra note 8, at 505. However, over time this negative perspective on funding class actions may erode.

47. In Australia, third-party funding was challenged on the basis that it turned what was intended as an opt-out regime into an opt-in regime. However, the high court upheld the practice on the grounds that it provided access to the court in situations where opt-out class actions were financially too risky. Campbell's Cash and Carry Pty Ltd v. Fostif Pty Ltd (2006) HCA 41(Austl.); Fostif Pty Ltd v. Campbell's Cash and Carry Pty Ltd (2005) NSWCA 83(Austl.); Multiplex Funds Management Limited Pty Ltd v. P. Dawson Nominees Pty Ltd (2007) FCAFC 2000 (Austl.). 
restrictive class action procedures or legal financing regimes - and also in some jurisdictions that forbid class actions altogether-is for a collection agent to offer to purchase the claims of individual claimants. Once claims are assigned to it, the agent can appear in court as a single plaintiff. Funding for entities that have adopted this litigation model is also being provided by third-party funders that invest in class actions. ${ }^{48}$

Other aspects of legal regimes also may hinder or hamper the use of class action procedures. The availability of damages beyond mere compensation-for example, punitive damages or disgorgement of profits or statutory damages that allow a multiplier of actual damages such as "treble damages" under United States anti-trust doctrineincrease the incentive to file class actions. The potential in the United States for a jury trial - however remote - may also increase the incentive to file a class action where the likelihood of a favorable jury verdict seems great.

\section{Alternatives to Class ACtions: Group PROCEEDINGS AND ADMINISTRATIVE SCHEMES}

In the United States mass claims that arise out of the same facts and law are usually collected and transferred to a single court and judge for pre-trial management purposes under the federal multi-district litigation statute (MDL). ${ }^{49}$ Once the transferee judge has ruled on significant substantive motions, including motions to dismiss, motions for summary judgment, and motions for class certification, as well as admissibility of expert evidence and key documents, the litigation usually settles. ${ }^{50}$ The

48. See Online Platform Launched for European Customer Claims against Volksvagen, (April 24, 2016), http://www.hausfeld.com/news/eu/online-platform-launched-for-european-customerclaims-against-volkswagen. Michael Hausfeld, a leading American class action lawyer, has successfully used this strategy for anti-competition (anti-trust) litigation in Europe. His firm is acting for those who assign their claims to the advertised collecting entity; funding to Hausfeld is provided by Burford Capital, a leading third-party litigation funder headquartered in New York.

49. 28 U.S.C. $\S 1407$ (2012). Several states have adopted similar rules for consolidating cases filed in different courts but arising out of the same facts. These state rules are frequently referred to as "coordination rules" See, e.g.,

22 N.Y. Comp. Codes R. \& Regs. Tit, 22 §202.69; Cal. Civ. Proc. Code §404; Tex. R. Jud. Admin. 13; Ill. Sup. Ct. R. 384. In New Jersey they are referred to as "multicounty litigation rules." N.J. Rules of Civil Practice, 4:38A.

50. See, e.g. Martin Redish \& Julie Karaba, One Size Doesn't Fit All: Multidistrict Litigation, Due Process and the Dangers of Procedural Collectivism, 95 B.U. L. Rev 109, 128-29 (2015). Under the provisions of 28 U.S.C. $\$ 1407$ and the U.S. Supreme Court's holding in Lexecon Inc. $v$. Milberg Weiss Bershad Hynes \& Lerach, 523 U.S. 26 (1998), cases that are not settled either individually or as a result of an aggregate resolution must be returned to the district courts in which they were filed for final resolution. 
Group Litigation Order (GLO) in England plays a similar role in that jurisdiction. ${ }^{51}$

The United States MDL provides an alternative scheme for aggregating mass claims when class certification is deemed inappropriate. Since its inception in 1968, the number and scope of MDLs has grown, ${ }^{52}$ perhaps in part in response to restrictions on certifying class actions for mass injury claims imposed by the U.S. Supreme Court. In Germany, steadfast opposition to the adoption of a class action procedure to address mass claims led to the adoption of the Capital Market Investors Model Proceeding" (Kapitalanlegermusterverfahrensgesetz, popularly known as the $\mathrm{KapMuG}){ }^{53}$ Shareholders' lawsuits arising out of the same facts and law can be entered in a register in a single court. A single "model" case is then selected for the court to investigate and decide. As that case works its way through the judicial process, action in all other cases on the register is stayed and the limitation period is tolled. The liability decision in the model case binds all cases on the register but remedies must be pursued subsequently on an individual basis. Unlike the United States MDL and the English GLO, both of which were intended to streamline pre-trial preparation of similar cases, the German procedure focuses on deciding the model case, a process that under German's civil law encompasses multiple decision-making stages, all directed by the judge. (Under the KapMuG, the case may also move frequently between the trial and appellate courts as key trial court decisions are appealed to the higher court.) In practice, the MDL, GLO and KapMuG share the tactic of selecting one or a few cases for trial (called "bellwether cases"

51. Christopher Hodges, Multi-PArty Actions 29-46 (2001).

52. According to John Rabiej of the Duke Law School Center for Judicial Studies, "In 2014, there [were] 117,647 non-asbestos cases in MDLs representing 36\% of the total U.S. pending civil caseload. Excluding prisoner and social security actions from the U.S. pending civil caseload, which typically (though not always) take little time of article III judges, the 117,647 non-asbestos cases in MDLs represent about $45 \%$ of the U.S. totals." Letter from John Rabiej, Duke Law School Center for Judicial Studies, to Deborah Hensler, Stanford Law School (August 29, 2014) (emphasis in original) (on file with author). The proportion of pending cases that are part of a consolidated proceeding may somewhat overestimate the importance of MDL litigation since MDL litigation typically pends for a longer time than ordinary civil litigation. The rate of MDL denials has increased recently. Whether this portends a sea change in the judiciary's willingness to aggregate multi-district cases or is merely a random deviation remains to be seen. Amanda Bronstad, Multidistrict Litigation Panels Increasing Denials Reflect Heightened Scrutiny, NAT'L L.J._July 18, 2016), http://www.nationallawjournal.com/id=1202762777589/Multidistrict-Litigation-PanelsIncreasing-Denials-Reflect-Heightened-Scrutiny?slreturn=20160901165935.

53. For a description of the history and implementation of the KapMuG scheme, see Axel Halfmeier, Litigation Without End? The Deutsche Telekom Case and the German Approach to Private Enforcement of Securities Law, in CLASS ACTIONS IN CONTEXT, supra note 1, at 279-98. 
in the United States) and using the outcomes in those trials either to determine or influence the outcomes in all other cases in the group.

An alternative to class actions and group proceedings in many jurisdictions is to create publicly or privately subsidized administrative compensation schemes for mass claims. Japan has a long tradition of establishing administrative compensation schemes for mass catastrophic injuries. $^{54}$ Several European countries have compensated asbestos disease victims through administrative schemes. ${ }^{55}$ The United States also has a long tradition of establishing special administrative compensation funds for victims of disease and government mistreatment, ${ }^{56}$ including coal miners suffering from black lung disease ${ }^{57}$ and victims of radioactive weapons' testing. ${ }^{58}$

In some recent instances in Europe, corporations have funded administrative compensation schemes at the direction of regulatory authorities. For example, in 2015, the Belgian financial market regulator ordered financial institutions that had sold interest rate swaps to small and medium-sized enterprises (SMEs) that suffered financial losses as a result of these purchases to establish a program to compensate the SMEs "as a commercial gesture." 59 In the Netherlands, where the financial regulator lacks the authority to issue an order compelling financial institutions to establish such a compensation scheme, it instead recommended to the Ministry of Finance that a "committee of

54. See, e.g., Ministry OF THE ENVIRONMENT: JAPAN, LESSONS LEARNED FROM MiNAMATA DISEASE AND MERCURY (Sept. 2013), https://www.env.go.jp/chemi/tmms/pr-m/mat01/en_full.pdf; Eric Feldman, Compensating the Victims of Japan's 3-11 Fukushima Disaster, 16 ASIAN-PAC. L. \& POL'Y J. 127 (2015); OECD NUCLEAR ENERGY AGENCY, JAPAN'S COMPENSATION SYSTEM FOR Nuclear Damage AS Related to the TePCo Daichi Nuclear Accident (2012), https://www.oecd-nea.org/law/fukushima/7089-fukushima-compensation-system-pp.pdf.

55. Albert Azagra-Malo, Asbestos Injuries Compensation Funds in France and Belgium, SSRN (July 23, 2007), http://papers.ssrn.com/sol3/papers.cfm?abstract_id=1371453.

56. See, e.g., Michele L. Dauber, The War of 1812, September 11th, and the Politics of Compensation, 53 DePAUL L. REV. 289, 289 (2013).

57. Sandy Smith, Dirty Little Secret: A Backlog of Miners' Claims Leaves Miners Waiting for Help, EHS TODAY (April 14, 2015), http://ehstoday.com/msha/dirty-little-secret-backlog-blacklung-claims-leaves-miners-waiting-help.

58. Jessica Boehm, 64 Years After Nuclear Tests, Some Downwinders Still Wait for Compensation, CRONKITE NEWS_January 28, 2015), http://cronkitenewsonline.com/2015/01/64years-after-nuclear-tests-some-downwinders-still-wait-for-compensation/.

59. Correspondence with Prof. Stefaan Voet, Katholick University of Leuven (Belgium), October 4, 2016 (on file with author). Interest-rate swaps are tradeable derivative instruments that allow borrowers and lenders to exchange fixed-rate interest obligations for floating interest rate obligations. Depending on fluctuations in interest rates either the borrower or lender may benefit from the exchange ("swap"). Like most financial instruments traded on the market, these derivatives carry substantial risks. When small and medium-sized business enterprises got into trouble as a result of purchasing interest rate swaps from financial institutions, questions were raised in Belgium, the Netherlands and the U.K. about whether the transactions violated legal rules. 
independent experts" be established to design a scheme and order the financial institutions to implement it. $^{60}$ In another example, the European Commission accepted the offer of Deutsche Bahn (DB) - the German national railway company - to settle a competition (anti-trust) action brought by the Commission by changing DB's pricing structure and reducing prices on railroads that were negatively affected by DB's allegedly anti-competitive behavior. Commentators have referred to this as an example of "regulatory redress"-i.e. compensation ordered by public regulators in lieu of or in addition to other sanctions. ${ }^{61}$

Although promoted as more efficient (and perhaps fairer) approaches to delivering compensation to victims of external forces and events, a consistent pattern of complaints across administrative programs established to assist different sorts of victims in different countries suggests that in practice such programs often struggle to serve the purposes for which they are intended. Often the number of eligible recipients who come forward as well as their needs exceed estimates (frequently developed in the absence of comprehensive data on how many people were injured and to what degree). Programs subsidized by government are frequently underfunded and funding problems can increase as programs drag on beyond the expected date of termination. Programs initially funded by private entities may appeal for government assistance when the initial appropriation to support the fund runs out. ${ }^{62}$

The widely-perceived success of the 9/11 compensation program,

60. Femke de Vries \& Bonne van Hattam, Address at the Groningen Centre for European Financial Services Law conference: Financial Supervision and Civil Liability in Mass Damage Cases: The Case of Interest Rate Swaps in the Netherlands and the U.K., (September 30, 2016).

61. Deutsche Bahn I, case no. 39678, http://ec.europa.eu/competition/elojade/isef/index.cfm. See also European Commission, Press Release. Antitrust: Commission accepts legally binding commitments from Deutsche Bahn concerning pricing of traction current in Germany (December 18, 2013), http://europa.eu/rapid/press-release_IP-13-1289_en.htm. The price reduction was intended to compensate the other railroad companies for elevated prices during the period before DB's new policies would significantly affect market pricing, not for the fact that they had paid higher prices in the past because of DB's anti-competitive practices.

62. For example, in 1970, Grunenthal, the German manufacturer of Contergan, a drug marketed to pregnant women as a remedy for "morning sickness" that was soon linked with birth defects, created a special purpose foundation to provide compensation to victims. The foundation was initially funded with a grant from Grunenthal of 100 million Deutsche Marks, plus a contribution by the German government of 300 million Deutsche Marks. As victims continued to come forward over the years, the foundation's funds were depleted and the government was pressured to step in to provide ongoing funding. In response to political pressure from victims in the past few years, Grunenthal agreed to contribute another 50 million Euros. Contergan was known as Thalidomide in the United States, where the U.S. Food and Drug Agency refused approval to market and distribute it. I am grateful to Prof. Axel Halfmeier of Leuphana University (Germany) for providing the information on the German Contergan compensation scheme (correspondence on file with author). 
established and subsidized by the U.S. federal government to compensate families of the victims of the terrorist attacks, seems to have renewed interest in administrative compensation schemes as an alternative to litigation for mass claims. Kenneth Feinberg, the Special Master who designed and managed the 9/11 compensation program, has since been called upon by corporate defendants to design programs offering compensation to victims of the British Petroleum Oil Spill in the Gulf of Mexico and the General Motors ignition switch defect. ${ }^{63}$ The attractiveness of this new breed of no-fault systems in which corporations without conceding legal liability offer compensation to victims in an effort to limit the corporation's ultimate financial responsibility as well as reputational loss appears to be growing. When news of Volkswagen's scheme to fool emissions control equipment into thinking their diesel-powered cars complied with air quality standards burst on the scene, Volkswagen of America announced that it had hired Feinberg to manage a compensation facility along the lines of the BP claims facility that he administered for the British petroleum corporation. ${ }^{64}$ No doubt reflecting the fact that such schemes are only attractive to corporations when the threat of private litigation or public enforcement is real, Volkswagen's German parent company asserted that it has no plans to offer German consumers similar access to compensation.

A third alternative to class actions that has been promoted in Europe in an effort to divert political attention from litigation solutions is alternative dispute resolution outside court systems. Although the European Commission to date has been unable to reach consensus on a mandate for member states to adopt class action procedures, in May 2013 the Commission issued a mandate directing member states to establish by July 2015 alternative dispute resolution procedures for resolving

63. Ross Barkan, Meet Ken Feinberg: The Master of Disasters, New York OBSERVER (March 9, 2016), http://observer.com/2016/03/meet-ken-feinberg-the-master-of-disasters/. Feinberg also administered government-sponsored programs for victims of the Boston Marathon bombings and victims of mass shootings in schools and entertainment venues.

64. Chris Woodyard, Volkswagen Hires Kenneth Feinberg to Handle Diesel Cases, USA TODAY (December 18, 2015), http://www.usatoday.com/story/money/cars/2015/12/17/volkswagenkenneth-feinberg/77495258/; Martine Powers, Ken Feinberg on VW: I will Have Ultimate Authority, POLITICO (January 25, 2016), http://www.politico.com/tipsheets/morningtransportation/2016/01/kenneth-feinberg-on-vw-i-will-have-ultimate-authority-more-takata-inflatorsdeemed-defective-dmv-survives-the-snowpocalypse-212326; Ken Feinberg on the Volkswagen Compensation Fund Process, BLOOMBERG News (February 12, 2016), http://www.bloomberg.com/news/videos/2016-02-12/ken-feinberg-on-the-volkswagencompensation-fund-process. 
consumer disputes outside their court systems. ${ }^{65}$ The lengthy directive (which was accompanied by a directive to establish on-line dispute resolution mechanisms for cross-border online purchases) spelled out in great detail the issues member states need to consider in designing procedures to assure their fairness to consumers and traders. ${ }^{66}$ Among the advocates for the consumer ADR directive were corporate lobbyists who hoped that the mandate would impede the development of a European Commission directive for member states to adopt class action procedures for economic disputes.

Studies published in the run-up to the adoption of the consumer ADR directive uncovered a host of existing out-of-court dispute resolution mechanisms in European countries, operated by private businesses, trade associations, and public entities. ${ }^{67}$ As is true also in the United States, assembling data to assess the performance of these mechanisms was difficult, perhaps contributing to the provisions in the European Commission's consumer ADR directive mandating the collection and publication of performance statistics. ${ }^{68}$ Missing from the published research is any discussion of the existing mechanisms' ability to deal with mass claims that arise within relatively short time periods (as in the Volkswagen debacle). Anecdotal evidence from the United States suggests that like courts, ${ }^{69}$ out-of-court dispute resolution mechanisms struggle to dispose of such claims expeditiously, for much the same reasons as challenge court dispute resolution systems.

65. $2013 \quad$ O.J. (L $\quad 165) \quad 32013$ L0011, http://eur-lex.europa.eu/legalcontent/EN/TXT/?uri=celex\%3A32013L0011

66. Interestingly, in the light of the U.S. Supreme Court jurisprudence upholding mandatory pre-dispute arbitration clauses in adhesive contracts - including clauses that bar claimants from proceeding collectively in any forum - the European Commission's directive specifies that an "agreement between a consumer and a trader to submit complaints to an ADR entity is not binding on the consumer if it was concluded before the dispute has materialized and if it has the effect of depriving the consumer of his right to bring an action before the courts for the settlement of the dispute." Directive 2013/11/EU, of the European Parliament and of the Council of 21 May 2013 on Alternative Dispute Resolution for Consumer Disputes and Amending regulation (EC) No 2006/2004 and Directive 2009/22/EC, 2013 O.J. (L 165) 63, 74-75.

67. CHRISTOPHER HODGES ET. AL., CONSUMER ADR IN EUROPE (2012).

68. 2013 O.J. (L 165) at 77.

69. See, e.g., Deborah Hensler et al., Class Action Dilemmas: Pursuing Public GOALS FOR PRIVATE GAIN 339-98 (2000) (describing the inability of corporate complaint resolution mechanisms to address customers' complaints about property damage due to faulty construction products when the mechanisms received massive numbers of such complaints). 


\section{CONSEQUENCES}

Given the sharp and protracted controversy that has accompanied the introduction of class actions in virtually all jurisdictions, ${ }^{70}$ and the important concerns that have been raised about potential uses and abuses of collective litigation, one might expect that jurisdictions would be carefully tallying the frequency and circumstances in which class actions are filed and collecting systematic information about class action outcomes. ${ }^{71}$ Alas, that is not the case. To my knowledge, no jurisdiction publishes official statistics on the number of complaints filed in which plaintiffs seek to proceed collectively. No one knows how many class actions are filed annually in federal or state courts in the United States, much less the characteristics or outcomes of these cases. ${ }^{72}$ Professors Vince Morabito and Alon Klement have compiled comprehensive databases on the number class filings in Australia $^{73}$ and Israel $^{74}$

70. Stefaan Voet, Deborah Hensler \& Vince Morabito, Class Actions Across the Atlantic: From Guarded Interest to European Policy, in process (on file with author).

71. One might imagine a jurisdiction deciding to adopt a class action on a "trial" basis and commission research to study objective and subjective outcomes. This type of research was commissioned by state and federal courts in the United States to assess the consequences of alternative dispute resolution procedures, and by Congress in 1990 to assess the outcomes of the Civil Justice Reform Act of 1990 (a package of civil procedure reforms intended to expedite civil litigation and reduce its expense). For a review of empirical research on alternative dispute resolution programs, see Deborah Hensler, Our Courts, Ourselves: How ADR is Transforming the U.S. Court System, 108 PENN STATE L. REV. 165 (2003). On research commissioned by Congress to evaluate the consequences of the Civil Justice Reform Act, see JAMES KAKALIK ET AL., AN Evaluation of Case Management Under the Civil Justice Reform ACt (1990). However, investing in serious research on civil procedure reform seems to have gone out of favor in the United States.

72. On the lack of empirical data on U.S. class actions and reasons for this lack, see Deborah Hensler, Happy 50 th Anniversary, Rule 23! Shouldn't We Know You Better After All This Time?, U. PENN. L. REV. (forthcoming).

73. Vince Morabito, An Empirical Study Of Australia's Class Action Regimes, First Report: Class Facts And Fion (Dec. 2009), http://globalclassactions.stanford.edu/sites/default/files/documents/Australia_Empirical_Morabito_2 009_Dec.pdf; Vince Morabito, An Empirical Study Of Australia's Class Action Regimes, Second Report: Litigation Funders, Competing Class Actions, Opt Out Rates, Victorian Class Actions And Class Representatives, $\quad$ (Sept. 2010), http:/globalclassactions.stanford.edu/sites/default/files/documents/Vince\%20Morabito\%202nd\%20 Report.pdf [hereinafter Morabito 2010]; Vince Morabito, An Empirical Study of Australia's Class Action Regimes, Third Report: Class Action Facts and Figures-Five Years Later (Nov. 14, 2014), http://papers.ssrn.com/sol3/papers.cfm?abstract_id=2523275 [hereinafter Morabito 2014]; Vince Morabito, An Empirical Study of Australia's Class Action Regimes, Fourth Report: Facts and Figures on Twenty-Four Years of Class Actions in Australia, (Aug. 3, 2016).

74. Alon Klement et al., Class Actions in Israel-An Empirical Perspective, (2014), http://elyon1.court.gov.il/heb/Research\%20Division/doc\%5C25122014.pdf [hereinafter Klement 2014]. See also Alon Klement \& Keren Weinshall, Cost Benefit Analysis of Class Actions: An Israeli Perspective, 172 J. OF INSTITUTIONAL AND THEORETICAL ECON. 75 (2016). 
respectively, which permit observation of trends in filings and provide some additional data on the characteristics of their cases and outcomes. Professors Theodore Eisenberg and Geoffrey Miller ${ }^{75}$ and Brian Fitzpatrick $^{76}$ have compiled comprehensive databases on federal class action settlements and attorney fee awards that permit analysis of the relationship between negotiated settlement amounts and fee awards and differences in settlements and fees across different case types. Several private entities monitor filings of shareholder (securities) class actions in Australia, Canada and the United States. But some private databases are unrepresentative or incomplete and because the data do not have a government imprimatur they are subject to challenge, particularly when relied on in heated debates over adopting or amending collective procedures.

Morabito found that from 1992 (when Australia's federal class action statute became effective) to 2014, 329 class actions were filed, an average of fifteen per year. Annual filings diminished in the second half of this period, by comparison to the earlier period, and the composition of the class action caseload shifted, so that in the more recent period shareholder suits predominated. The shift to shareholder suits likely reflects the increasing importance of third-party funding in Australia's class action practice. Class action filings appear to represent less than 1 percent of all federal civil filings in Australia. ${ }^{77}$

Klement found that from 2008 (when Israel's comprehensive class action statute became effective) to 2012 (the most recent year for which he compiled data), annual class action filings rose steadily, peaking at 820. A total of 2,004 class action lawsuits were filed from 2007-2012. Consumer cases accounted for about three-quarters of the Israeli class action caseload. $^{78}$

Surprisingly, the per capita rate of class action filings appeared higher in Israel than in the United States. ${ }^{79}$ A decade ago, I estimated the number of class actions filed in the federal and state courts in the United

75. Theodore Eisenberg \& Geoffrey P. Miller, Attorneys' Fees and Expenses in Class Action Settlements: 1993-2008, 7 J. OF EMPIRICAL LEGAL STUD. 248 (2010).

76. Brian T. Fitzpatrick, An Empirical Study of Class Action Settlements and their Fee Awards, 7 J. OF EMPIRICAL LEGAL STUD. 811 (2010).

77. Hensler, Enforce Marketplace Regulations, supra note 8, at 251, 253 (summarizing Morabito 2010 and Morabito 2014, supra note 59). Contrary to claims by the U.S. Chamber of Commerce, there is no evidence that third-party funding has increased the frequency of ordinary or class action lawsuits. Hensler, Third-Party Financing, supra note 8, at 499, 524.

78. Hensler, Enforce Marketplace Regulations, supra note 8, at 252-53 (summarizing Klement 2014, supra note 60).

79. Id. at 252 . 
States by piecing together incomplete data; according to that estimate, about 6,500 class action complaints were then being filed, about one percent of the total civil damage caseload in state and federal courts. ${ }^{80}$

Data from civil law jurisdictions regarding cases filed under their more recently enacted class action and group proceedings statutes are sparse. Tzankova and associates report that there have been between 300 and 400 cases filed under the Netherland's collective litigation statute (which does not provide monetary remedies) since its inception in 1995, and 9 petitions for approval of collective settlements negotiated under its collective settlement statute (WCAM) (which does provide money damages) since it was enacted in $2005{ }^{81}$ Halfmeier reports that there have been about twenty five cases filed using the German KapMuG procedure since it was adopted in 2005, most of which are still in process. ${ }^{82}$

Taken together these data suggest that in common law jurisdictions class actions are used sparingly (relative to the size of national caseloads of civil damage litigation) and tend to rise and fall in response to broader economic trends, as well as with precedential decisions. There is no evidence of class actions overwhelming any country's civil justice system. The small numbers of class actions and other collective proceedings filed in civil law jurisdictions likely reflect the combined effects of recent adoption and financial disincentives to bring such cases. As time goes on, those jurisdictions might or might not experience a rising tide of collective lawsuits.

Mere numbers of class actions filed by jurisdiction do not of course suffice to evaluate the merits and demerits of collective litigation, nor whether some forms of collective procedure are more effective at delivering compensation, produce fairer outcomes for claimants and

80. Id. (summarizing Deborah Hensler, Using Class Actions to Enforce Consumer Law, in Deborah Hensler, Handbook of Research on International Consumer law, (Geraint Howells et. al. eds., 2010). The appendix to Hensler, Third-Party Financing, supra note 8, explains how I constructed this estimate. Recent research suggests that only a fraction of U.S. class action filings in the United States are ever certified as class actions, indicating that the number of cases that are disposed of in class form is far smaller than the total number of class complaints filed. Reviewing data for different types of caseloads, I found certification rates ranging from about thirteen percent for class complaints arising from tort and contract law to fifty percent for securities class action complaints. Hensler, Enforce Marketplace Regulations, supra note 8, Table 4,. I have not been able to find comprehensive data on Canadian class actions either in the federal or provincial systems.

81. Correspondence with Prof. Ianika Tzankova, Tilburg University (Netherlands), October 2016 (on file with author).

82. Correspondence with Prof. Axel Halfmeier, Leuphana University (Germany) October 2016 (on file with author). 
defendants or - in jurisdictions that perceive private litigation as properly supplementing regulatory enforcement-contribute positively to regulating the behavior of market actors. The globalization of class actions has produced a "natural experiment" of the type that law and economic scholars frequently rely on to assess the outcomes of alternative legal policies. Unfortunately, we have yet to see such research on the consequences of adopting class action procedures either here in the United States or in other parts of the world. 